\title{
Flow cytometric analysis of granulosa cells from developing rat follicles*
}

\author{
I. M. Rao†, W. C. Allsbrook, Jr $\ddagger$, B. A. Conway†, J. E. Martinez
} J. R. Beck $\ddagger$, C. G. Pantazis $\ddagger$, T. M. Mills $\dagger$, E. Anderson $\S$ and V. B. Mahesh $\dagger$ $\dagger$ Department of Physiology and Endocrinology, $\ddagger$ Department of Pathology Medical College of Georgia, Augusta, GA 30912, USA; §Department of Anatomy and Cellular Biology and Laboratory for the Human Reproduction and Reproductive Biology, Harvard Medical School, Boston, MA 02115, USA

\begin{abstract}
Summary. Immature rats were treated with diethylstilboestrol (DES) or pregnant mares' serum gonadotropin (PMSG) and forward angle light-scatter (FALS) and $90^{\circ}$ light-scatter $\left(90^{\circ} \mathrm{LS}\right)$ signals were used to measure the size and the granularity (internal organization) of the granulosa cells, respectively. The results confirmed the presence of two major populations of granulosa cells in the ovaries of both groups of rats, with the same percentage of larger cells in both treatments (52.3\% in DES, $49.5 \%$ in PMSG). Since DES treatment brings about granulosa cell growth while PMSG treatment causes growth and differentiation, it is evident that there is heterogeneity in granulosa cell sizes during different states of growth and differentiation. There was also heterogeneity in sizes of granulosa cells harvested from follicles of small $(<210 \mu \mathrm{m})$, medium $(210$ $420 \mu \mathrm{m})$ and large $(>420 \mu \mathrm{m})$ diameter. Quadrant analysis of granulosa cells in various fractions collected from Percoll gradients suggested an increase in granularity in the small and large granulosa cell populations. Cell cycle analysis of small and large granulosa cell populations collected from large follicles of rats treated with PMSG indicated that each population was distributed in $G_{0} / G_{1}, S$ and $G_{2} / M$ phases. These results demonstrate that populations of small and large granulosa cells exist in rat ovarian follicles during various stages of growth and differentiation.
\end{abstract}

Keywords: flow cytometry; granulosa cells; heterogeneity; follicle isolation; DNA analysis; rat

\section{Introduction}

Rao et al. (1991) have shown evidence of heterogeneity in steroidogenesis in granulosa cells of developing rat ovaries. In addition, light microscopy revealed the distribution of granulosa cells into two major populations based on size. The present studies were designed to examine the heterogeneity in cell sizes by flow cytometry using forward angle light scatter (FALS) and $90^{\circ}$ light scatter $\left(90^{\circ}\right.$ LS).

Several approaches were used to elucidate the role of small and large granulosa cell populations in folliculogenesis. In the first approach, we examined whether the small and large granulosa cells occurred because of different stages of differentiation. Granulosa cells from the ovaries of diethylstilboestrol- and PMSG-treated rats were examined for size heterogeneity; diethylstilboestrol treatment induces granulosa cell growth and PMSG both growth and differentiation. Furthermore, since the large preovulatory follicles in PMSG-treated rats were known to be at an advanced state of differentiation, granulosa cells from follicles of $<210 \mu \mathrm{m}, 210-420 \mu \mathrm{m}$ and $>420 \mu \mathrm{m}$ diameter

\footnotetext{
*Reprint requests to Dr V. B. Mahesh.
} 
were examined for size differences. Such a study would also help to determine whether small granulosa cells were found in small follicles and large granulosa cells were found in large follicles. The second approach was to examine whether the large cell population is derived from the small cells due to differentiation, in which case the large cells should no longer cycle, or whether both small and large cell populations have cyclic cells. To answer this question cell cycle analysis of both small and large cell populations was undertaken.

\section{Materials and Methods}

Sprague-Dawley female rats were purchased fom Holtzman Inc., Madison, WI, USA. They were treated with (a) diethylstilboestrol (Steraloids, Wilton, NH, USA; $2 \mathrm{mg} / \mathrm{rat}$ in $0.2 \mathrm{ml}$ propylene glycol) injected at 0 and $24 \mathrm{~h}$ starting on Day 25. Rats were killed after 48 h (Day 27); or (b) PMSG (NICHD, NIH, USA; 8 i.u./rat in $0.2 \mathrm{ml}$ saline) injected on Day 28 and killed 50-52 h later for harvesting granulosa cells. The granulosa cells from the ovaries were isolated using the procedure of Campbell (1979), as modified by Rao et al. (1991). In this procedure ovaries were initially punctured and then incubated in EGTA (Sigma Inc., St Louis, MO, USA) followed by hypertonic sucrose (Sigma Inc.) at $37^{\circ} \mathrm{C}$ in an atmosphere of $5 \% \mathrm{CO}_{2}, 95 \%$ air. The ovaries were then gently squeezed to release granulosa cells into McCoy's 5A (Sigma) medium. Some batches of granulosa cells from both treatment groups were separated on a continuous $15-45 \%$ Percoll gradient and 12 fractions ranging from low to high density Percoll (Pharmacia LKB Biotechnology Inc., Piscataway, NJ, USA) were collected as described by Rao et al. (1991). The granulosa cells in these fractions were then analysed by flow cytometry.

Follicle isolation and separation based on size. The procedure used was adapted from that described by Roy \& Greenwald (1985) as modified by Conway et al. (1990). Briefly, collagenase from Clostridium histolyticum (Sigma; Type IA 760 units/mg) was dissolved in McCoy's 5A medium with $25 \mathrm{~mm}$-Hepes (Sigma; pH 7.0) at concentration of $3040 \mathrm{U} / \mathrm{ml}$. DNase from bovine pancreas (Sigma; $400 \mathrm{U} / \mathrm{ml}$ ) was dissolved in McCoy's 5A medium ( $\mathrm{pH} 7.0$ ). Both enzymes were prewarmed to $37^{\circ} \mathrm{C}$ (total volume $=2 \mathrm{ml}$ ) before exposure to the ovaries.

Ovaries were collected, cleaned of fat and then dissected into small pieces in ice-cold McCoy's $5 \mathrm{~A}$ medium $+1.5 \%$ BSA (ICN Immunobiologicals, Costa Mesa, CA, USA). The ovaries were further disrupted and follicles released by incubation in the collagenase/DNase mixture for $20 \mathrm{~min}$ at $37^{\circ} \mathrm{C}$. McCoy's 5A medium containing $1 \%$ BSA was then added to dilute the enzyme and the tube centrifuged at $45 \mathrm{~g}$ for $3 \mathrm{~min}$ at $4^{\circ} \mathrm{C}$. The supernatant was decanted and the pellet resuspended in fresh medium. Gentle agitation with a Pasteur pipette further dissociated the ovaries. The mixture was filtered through two layers of gauze to remove large pieces of tissue and then centrifuged at $45 \mathrm{~g}$ at $4{ }^{\circ} \mathrm{C}$ for $3 \mathrm{~min}$. The resulting pellet was resuspended in $1 \mathrm{ml} \mathrm{McCoy}$ 's $5 \mathrm{~A}$ medium $+0.1 \%$ BSA and then layered onto a $10-$ $50 \%$ Percoll continuous gradient and centrifuged at $45 \mathrm{~g}$ for $3 \mathrm{~min}$ at $4^{\circ} \mathrm{C}$. Samples of $2 \mathrm{ml}$ were removed from the top of the gradient. The follicles in each sample were washed with $2 \mathrm{ml} 0.1 \%$ BSA in McCoy's 5A medium and then centrifuged at $45 \mathrm{~g}$ for $3 \mathrm{~min}$ at $4^{\circ} \mathrm{C}$. The follicles were further purified by passing the preparations through Teflon filters (Spectrum Medical Industries Inc., Los Angeles, CA, USA) of 420, 210 and $105 \mu \mathrm{m}$ pore size. This procedure removed most of the individual and clumped granulosa cells, broken follicles and other debris and partitioned the follicle population into small $(<210 \mu \mathrm{m})$, medium $(210-420 \mu \mathrm{m})$ and large $(>420 \mu \mathrm{m})$ sizes. The resulting isolated follicles in each size range were resuspended in a final volume of $1 \mathrm{ml}$ and $50 \mu \mathrm{l}$ from each fraction were analysed for the number, size and appearance of the follicles. Granulosa cells were harvested from the small, medium and large size follicles using the method of Rao et al. (1991).

Analysis of granulosa cells by flow cytometry. Granulosa cells were analysed on an Epics 752 flow cytometer (Coulter Electronics, Hialeah, FL, USA), using a 5-W argon laser emitting at $488 \mathrm{~nm}, 300 \mathrm{~mW}$ output. Single cell suspensions of granulosa cells in McCoy's 5A medium were analysed for forward angle light scatter (FALS), and $90^{\circ}$ light scatter $\left(90^{\circ} \mathrm{LS}\right)$, the former being an estimate of relative cell size and the latter a measure of granularity. The FALS detector was set to a gain of 2 , and the $90^{\circ} \mathrm{LS}$ detector to a high voltage of 900 . A minimum of 10000 cells was counted in each experiment and the data displayed as single-parameter frequency distribution histograms ( $x$ axis $=$ increasing forward angle light scatter; $y$ axis = number of cells), or dual-parameter histograms ( $x$ axis $=90^{\circ} \mathrm{LS}, y$ axis $=$ FALS). The histograms were subsequently stored for further analysis.

Analysis of single-parameter histograms. The FALS single-parameter histogram demonstrated two distinct populations of cells. The percentage of cells in each population was determined by placing an electronic gate at the nadir between the two populations and calculating the percentage of cells to the left and to the right of the gate. The cells to the right of the gate have greater light scatter and are larger. Clumps of granulosa cells (Channel 256) were electronically excluded from analyses.

Cell sorting and viability check. Granulosa cells were sorted using the gate settings derived from the FALS $90^{\circ}$ LS pattern that classified the populations into small and large populations. The sorted cells were collected in McCoy's 5A medium for subsequent viability assessment by microscopic examination. About $100-400$ cells from each sample were checked for viability by erythrosin B exclusion using a haemocytometer. 
Quadrant analysis of dual-parameter histograms. The dual parameter FALS $-90^{\circ}$ LS histograms were analysed using Quadstat software (Coulter Electronics, Hialeah, FL, USA). Briefly, gates were set for both the FALS and $90^{\circ}$ LS parameters. As with the single-parameter histograms, the FALS gate was set at the nadir between the small and large granulosa cell populations. The $90^{\circ} \mathrm{LS}$ gate was set at a channel to the right of the maximum density of cells. The program calculated the percentage of cells of each size in each of the 4 quadrants defined by the FALS and $90^{\circ} \mathrm{LS}$ gates. Clumps of cells (Channel 64) were electronically excluded from the analysis. In this series of experiments Quadrant 1 contained the population of large granulosa cells with low $90^{\circ} \mathrm{LS}$, Quadrant 2 contained the large granulosa cells with high $90^{\circ} \mathrm{LS}$, Quadrant 3 consisted of the population of small granulosa cells with low $90^{\circ} \mathrm{LS}$ while Quadrant 4 contained the small granulosa cells with high $90^{\circ}$ LS signal.

DNA analysis. Granulosa cell suspensions were counted on a Coulter D2N cell counter. An aliquant containing $1 \times 10^{6} \mathrm{cells} / \mathrm{ml}$ was placed in a $15 \mathrm{ml}$ capped polystyrene tube and $1 \mathrm{ml}$ heat-inactivated fetal calf serum was added. While vortexing the sample, $6 \mathrm{ml}$ cold $\left(4^{\circ} \mathrm{C}\right) 70 \%$ ethanol were added slowly and the fixed samples were stored at $4^{\circ} \mathrm{C}$. Immediately before analysis, samples were centrifuged for $4 \mathrm{~min}$ at $400 \mathrm{~g}$ and the supernatant was discarded. Samples were resuspended in $1 \mathrm{ml}$ of solution contaning $5 \%$ fetal calf serum (GIBCO Laboratories, Grand Island, NY, USA) in phosphate-buffered saline, $\mathrm{pH} 7 \cdot 4$, mixed and centrifuged for $5 \mathrm{~min}$ at $400 \mathrm{~g}$. The supernatant was discarded and the pellet was washed with $1 \mathrm{ml} 5 \%$ fetal calf serum in PBS and centrifuged. The supernatant was discarded and $100 \mu \mathrm{l}$ RNase A (Sigma Inc.; $500 \mathrm{IU} / \mathrm{ml}$ in 0.9\% saline) and $1 \mathrm{ml}$ propidium iodide solution (Calbiochem, San Diego, CA, USA; $5 \mu \mathrm{g} / \mathrm{ml}$ in $0.9 \%$ saline) were added and the samples were mixed. The samples were then incubated for 30 min at room temperature in the dark and then analysed for DNA content on an EPICS 752 with a 5-W argon laser emitting at $488 \mathrm{~nm}$. Analysis was done within $3 \mathrm{~h}$ after staining.

All the experiments were repeated 2 or 3 times. Representative data are shown in the 'Results'.

\section{Results}

\section{Forward angle light scatter and $90^{\circ}$ light scatter analysis of granulosa cells from diethylstilboestrol- and PMSG-treated rats}

To determine whether the granulosa cells exist as two major populations of cells or are present in a continuum of different cell sizes, granulosa cells from diethylstilboestrol-primed animals were examined by flow cytometry. The presence of two major populations of cells was detected by forward angle light scatter (FALS; Fig. 1a). Figure 1(b) is the two parameter $\left(90^{\circ} \mathrm{LS} v s\right.$ FALS) histogram obtained from the same sample. Again, two major populations of cell sizes are clearly evident.

The flow cytometric distribution pattern of granulosa cells from diethylstilboestrol-treated rats (Figs la \& b) has been confirmed by several repetitions of the experiment. For PMSG-treated rats (Figs 1c \& d), 2 major cell populations were found. The patterns of distribution were similar for diethylstilboestrol- and PMSG-treated rats. An electronic gate defining the FALS nadir between populations was set at Channel 56 and the percentages of each population were determined. The percentage of large granulosa cells was $52.26 \%$ in the diethylstilboestrol-treated group, and $49.54 \%$ in the PMSG-treated group. These values are similar and indicated that no appreciable shift in size had taken place during differentiation.

\section{Viability analysis of granulosa cells}

To rule out the possibility that the small granulosa cell population was only damaged or dead large cells, we examined the viability of the two populations from both treatment groups by the erythrosin-B exclusion method. Before sorting, small and large cells appeared to be equally viable. After sorting, using the same FALS settings as described in 'Methods', the small and large cell populations both showed similar viabilities and were not different from the viability before sorting (Table 1).

\section{Forward angle light scatter analysis of granulosa cells from follicles of different sizes}

To determine whether the different sizes of follicles contained different distributions of small and large granulosa cells, follicles from PMSG-treated rat ovaries were isolated by enzymic 

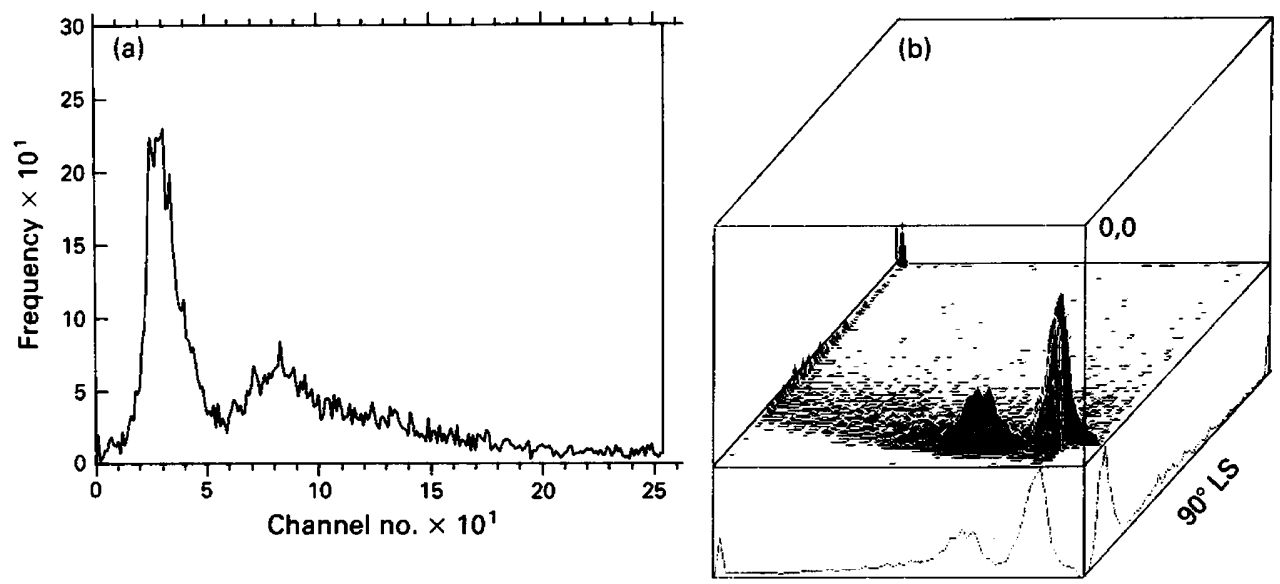

FALS
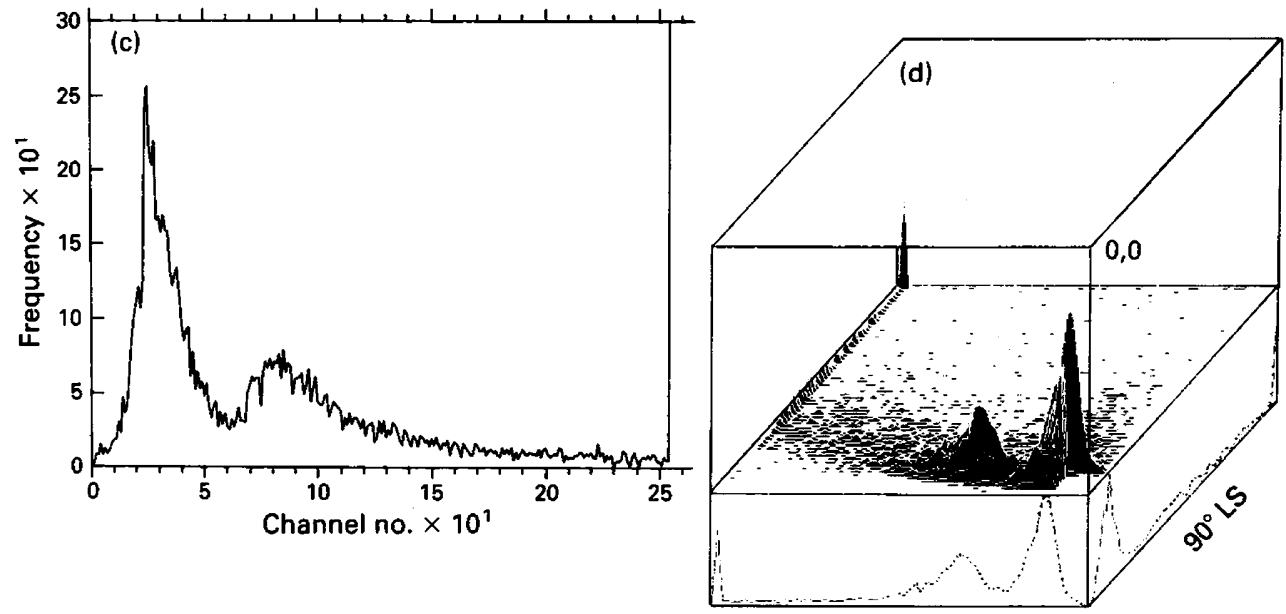

FALS

Fig. 1. Frequency distribution histograms showing forward angle light scatter (FALS) of pooled granulosa cells obtained from rat ovaries after treatment with $(a, b)$ diethylstilboestrol and (c, d) PMSG. (a) (c) single parameter; (b) (d) two parameters, expanded isometrically.

Table 1. Viability of granulosa cell populations

\begin{tabular}{llcc}
\hline & & \multicolumn{1}{c}{$\begin{array}{l}\text { Before } \\
\text { sorting }\end{array}$} & $\begin{array}{c}\text { After } \\
\text { sorting }\end{array}$ \\
\cline { 3 - 4 } Treatment & $\begin{array}{c}\text { Cell } \\
\text { type }\end{array}$ & (\% of total cells counted) \\
\hline Diethylstilboestrol & Unsorted & 56 & - \\
& Small & - & 47 \\
PMSG & Large & - & 49 \\
& Unsorted & 59 & - \\
& Small & - & 67 \\
& Large & - & 54 \\
\hline
\end{tabular}


digestion and separated into small $(<210 \mu \mathrm{m})$, medium $(210-420 \mu \mathrm{m})$ and large $(>420 \mu \mathrm{m})$ follicle sizes. Granulosa cells were harvested from each of the three follicle sizes and analysed by flow cytometry. Granulosa cells harvested in this manner were somewhat smaller overall, possibly due to the use of enzyme digestion of the ovarian tissue. Consequently, adjustments were made in the flow cytometer settings to correct for the smaller size by setting the gate defining the FALS nadir between populations at Channel 35. As shown in Fig. 2, the resulting FALS patterns were similar with large cells (Channels 35-256) representing $75 \cdot 9 \%, 85 \cdot 4 \%$, and $77 \cdot 1 \%$ of the total granulosa cells from small, medium and large follicles, respectively. In a repeat experiment the percentages of large cells were $72 \cdot 8 \%, 83 \cdot 6 \%$, and $74.7 \%$ of the total granulosa cells from small, medium and large follicles, respectively.

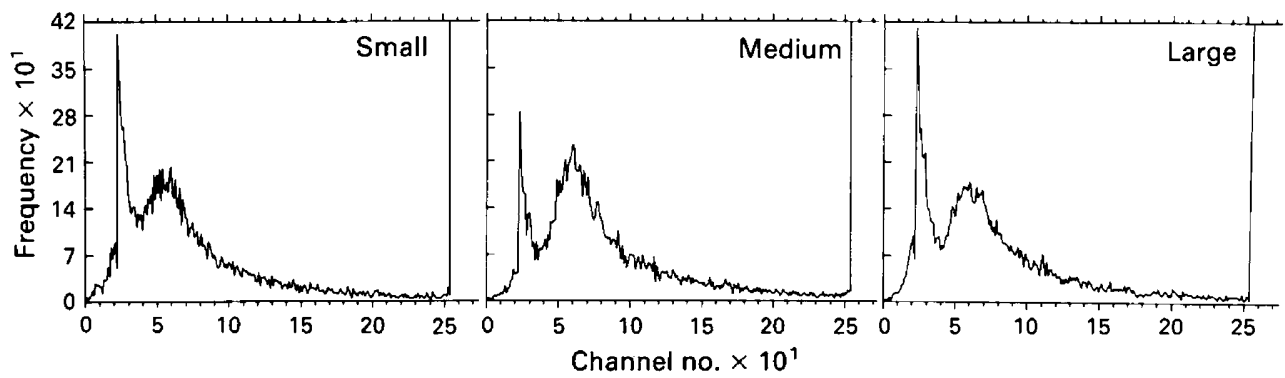

Fig. 2. Single-parameter frequency histogram showing FALS of pooled granulosa cells from small $(<210 \mu \mathrm{m}$ diameter $)$ medium $(210-420 \mu \mathrm{m}$ diameter $)$ and large $(>420 \mu \mathrm{m}$ diameter $)$ follicles from the ovaries of PMSG-treated rats.

\section{Forward angle light scatter analysis of granulosa cells in Percoll fractions}

Rao et al. (1991) showed that when granulosa cells from diethylstilboestrol- and PMSG-treated rat ovaries were separated on a $15-45 \%$ Percoll density gradient, there were functional differences in the production of oestradiol and progesterone in cell cultures. Analysis of cell populations by flow cytometry (Channel 56-256) of Percoll fractions 3-12 is shown in Table 2. Fractions 1 and 2 were not analysed because they were composed almost entirely of dead or damaged cells. There appeared to be an enrichment of large cells in Percoll fractions 3-7 for diethylstilboestrol-treated rats and Percoll fractions 3-6 in PMSG-treated rats. Beyond these fractions there was no further enrichment of large cells. The most probable explanation for the enrichment of the large cell number in the first few Percoll fractions followed by an arrest in enrichment in the later fractions is a change in cellular granularity of the small cells as measured by $90^{\circ} \mathrm{LS}$.

\section{Quadrant analysis of selected Percoll fractions}

To determine whether the above explanation is valid, quadrant analysis of the $90^{\circ} \mathrm{LS} v \mathrm{~s}$ FALS two-parameter histograms of the data in Table 2 was performed on selected fractions. Percoll fraction 3 for diethylstilboestrol-treated rat ovaries served as the baseline sample. The analysis was undertaken to determine whether there was a shift in $90^{\circ}$ LS between Fractions 3 and 11 , and whether the Fraction 7 represented an intermediate point in the shift. Using the gate settings derived from Fraction 3, Fractions 3, 7 and 11 for PMSG-treated rats were similarly examined. The FALS gate was set at Channel 13 (equivalent to Channel 56 in single-parameter 
Table 2. Percentage of large cells in Percoll gradients of granulosa cells from diethylstilboestrol- and PMSG-treated rats

\begin{tabular}{|c|c|c|c|c|}
\hline \multirow[b]{2}{*}{ Sample } & \multicolumn{2}{|c|}{ Diethylstilboestrol } & \multicolumn{2}{|c|}{ PMSG } \\
\hline & $\begin{array}{c}\text { Cells* } \\
\text { counted }\end{array}$ & $\begin{array}{c}\% \text { Large } \\
\text { cells }\end{array}$ & $\begin{array}{l}\text { Cells* } \\
\text { counted }\end{array}$ & $\begin{array}{c}\% \text { Large } \\
\text { cells }\end{array}$ \\
\hline Before fractionation & 9482 & $52 \cdot 26$ & 9413 & $49 \cdot 54$ \\
\hline \multicolumn{5}{|l|}{ Percoll fraction } \\
\hline 3 & 9969 & $40 \cdot 73$ & 9907 & $50 \cdot 33$ \\
\hline 4 & 9929 & $56 \cdot 21$ & 9799 & $71 \cdot 46$ \\
\hline 5 & 9755 & $68 \cdot 43$ & 9547 & $80 \cdot 96$ \\
\hline 6 & 9779 & $70 \cdot 54$ & 9399 & $81 \cdot 27$ \\
\hline 7 & 9550 & $76 \cdot 32$ & 9051 & $77 \cdot 52$ \\
\hline 8 & 9628 & $69 \cdot 34$ & 8811 & $70 \cdot 12$ \\
\hline 9 & 9547 & $67 \cdot 59$ & 8657 & $63 \cdot 84$ \\
\hline 10 & 9258 & $68 \cdot 41$ & 8370 & $62 \cdot 54$ \\
\hline 11 & 9299 & $61 \cdot 45$ & 8510 & $61 \cdot 67$ \\
\hline 12 & & & 8789 & $61 \cdot 83$ \\
\hline
\end{tabular}

*The clumps were eliminated showing the number of cells counted out of a representative 10000 cells counted from each sample.

Fractions 1 and 2 were eliminated as they contained mostly dead cells. DES fractions 11 and 12 were pooled and represented as Fraction 11.

analysis) and the $90^{\circ} \mathrm{LS}$ gate was set at Channel 15 (equivalent to Channel 64 in single-parameter analysis).

The cell distribution patterns are shown in Fig. 3. The data compiled in Table 3 show that, in Fraction 3 of diethylstilboestrol-treated material, small cells with increased granularity constituted $3.9 \%$ of the total small cell population while the large cells with increased granularity were $6.2 \%$ of the total large cell population. In Fracton 7 the number of small cells decreased significantly $(38 \cdot 3 \%)$ as compared to the number of small cells in Fraction 3, and the total number of large cells increased (181\%) as compared to the number of large cells in Fraction 3. This explained the enrichment of large cells observed. In Fraction 11 there were greater numbers of small cells than in Fraction 7. These cells were obviously more dense than those in Fractions 3 to 7 because they did not appear in less dense fractions of the Percoll gradient. This is also evident because there was a 2.3-fold increase in the percentage of small cells with a high $90^{\circ} \mathrm{LS}$ as compared with Fraction 3 values. Compared with Fraction 7, the percentage of cells with higher $90^{\circ} \mathrm{LS}$ was $3 \cdot 3$-fold greater in Fraction 11. These results indicate shifts in granularity in small cells from various fractions of diethylstilboestrol-treated material in the Percoll gradient.

A similar pattern of shift was observed in granulosa cells from PMSG-treated animals. Fraction 7 represented an intermediate stage in which the shift in the percentage of small cells with increased granularity had not taken place, although a 2.3-fold shift had occurred in large cells. The percentage of small cells with increased granularity in Fraction 11 for both treatment groups was the same. However, the shift in large cells with increased granularity in PMSG-treated rats was dramatic compared with that for diethylstilboestrol-treated rats $(20 \cdot 4 \%$ v $8 \cdot 2 \%)$.

\section{Cell cycle analysis of granulosa cells from the large follicles of PMSG-treated rats}

Using $90^{\circ} \mathrm{LS}$ and FALS as gating parameters, large and small cells from the large follicles of PMSG-treated rats were bit mapped and these regions were analysed for cell cycle distribution. The cell cycle analysis indicated that both large (Fig. 4D) and small (Fig. 4F) cell populations contained cells in the $G_{0} / G_{1}$ as well as the $S$ and $G_{2} / M$ phases. The peak at Channel $170-180$ probably 
(a)

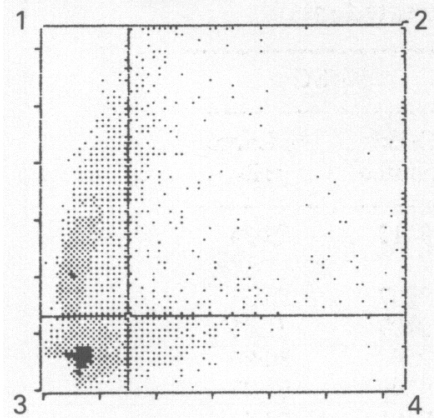

(d)

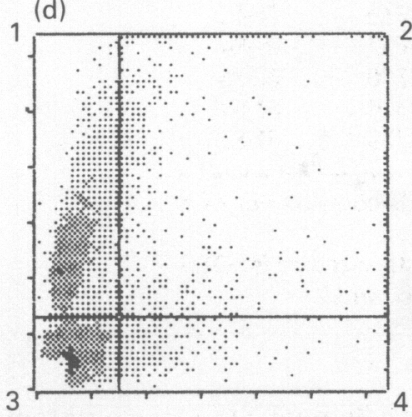

(b)

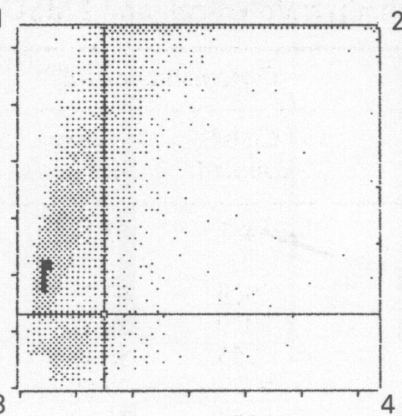

(e)

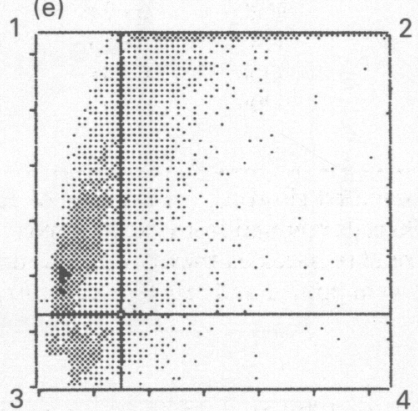

(c)
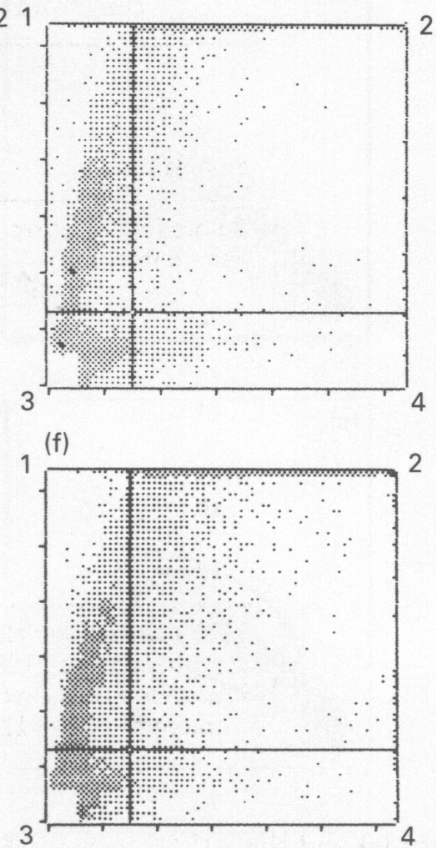

Fig. 3. Two-parameter frequency distribution histogram in $90^{\circ} \mathrm{LS} v s$ FALS including quadrant co-ordinates $\left(90^{\circ} \mathrm{LS}-15\right.$, FALS - 13) for quadrant analysis of granulosa cells from $(\mathrm{a}, \mathrm{b}, \mathrm{c})$ diethylstilboestrol- and (d, e, f) PMSG-treated rats after separation on Percoll gradient. Fractions 3, 7 and 11 are represented in (a) and (d), (b) and (e) and (c) and (f), respectively.

Table 3. Quantitative data of results from quadrant analysis of selected fractions showing increased granularity as shown by $90^{\circ} \mathrm{LS}$ signal (based on the settings used)

\begin{tabular}{|c|c|c|c|c|c|c|}
\hline & \multicolumn{3}{|c|}{ Small cells } & \multicolumn{3}{|c|}{ Large cells } \\
\hline & Total $^{a}$ & $\begin{array}{l}\text { Increased } \\
\text { granularity }\end{array}$ & $\%$ & Total $^{\mathbf{c}}$ & $\begin{array}{l}\text { Increased } \\
\text { granularity }\end{array}$ & $\%$ \\
\hline \multicolumn{7}{|c|}{ Diethylstilboestrol } \\
\hline Cell pool $^{\circ}$ & 4524 & 181 & $4 \cdot 0$ & 4943 & 768 & $15 \cdot 6$ \\
\hline Fraction 3 & 5907 & 231 & 3.9 & 4033 & 252 & $6 \cdot 2$ \\
\hline Fraction 7 & 2261 & 61 & $2 \cdot 7$ & 7285 & 690 & $9 \cdot 5$ \\
\hline Fraction 11 & 3583 & 323 & $9 \cdot 0$ & 5704 & 469 & $8 \cdot 2$ \\
\hline \multicolumn{7}{|l|}{ PMSG } \\
\hline Cell pool $^{e}$ & 4744 & 215 & 4.5 & 4655 & 787 & 16.9 \\
\hline Fraction 3 & 4916 & 270 & 5.5 & 4942 & 375 & 7.6 \\
\hline Fraction 7 & 2033 & 109 & $5 \cdot 4$ & 7009 & 1208 & $17 \cdot 2$ \\
\hline Fraction 11 & 3256 & 309 & $9 \cdot 5$ & 5225 & 1067 & 20.4 \\
\hline
\end{tabular}

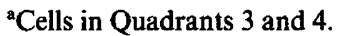

${ }^{\text {b } C e l l s ~ i n ~ Q u a d r a n t ~} 4$.

${ }^{\circ}$ Cells in Quadrants 1 and 2.

${ }^{d}$ Cells in Quadrant 2.

'Cells pooled before separation on Percoll gradient. 

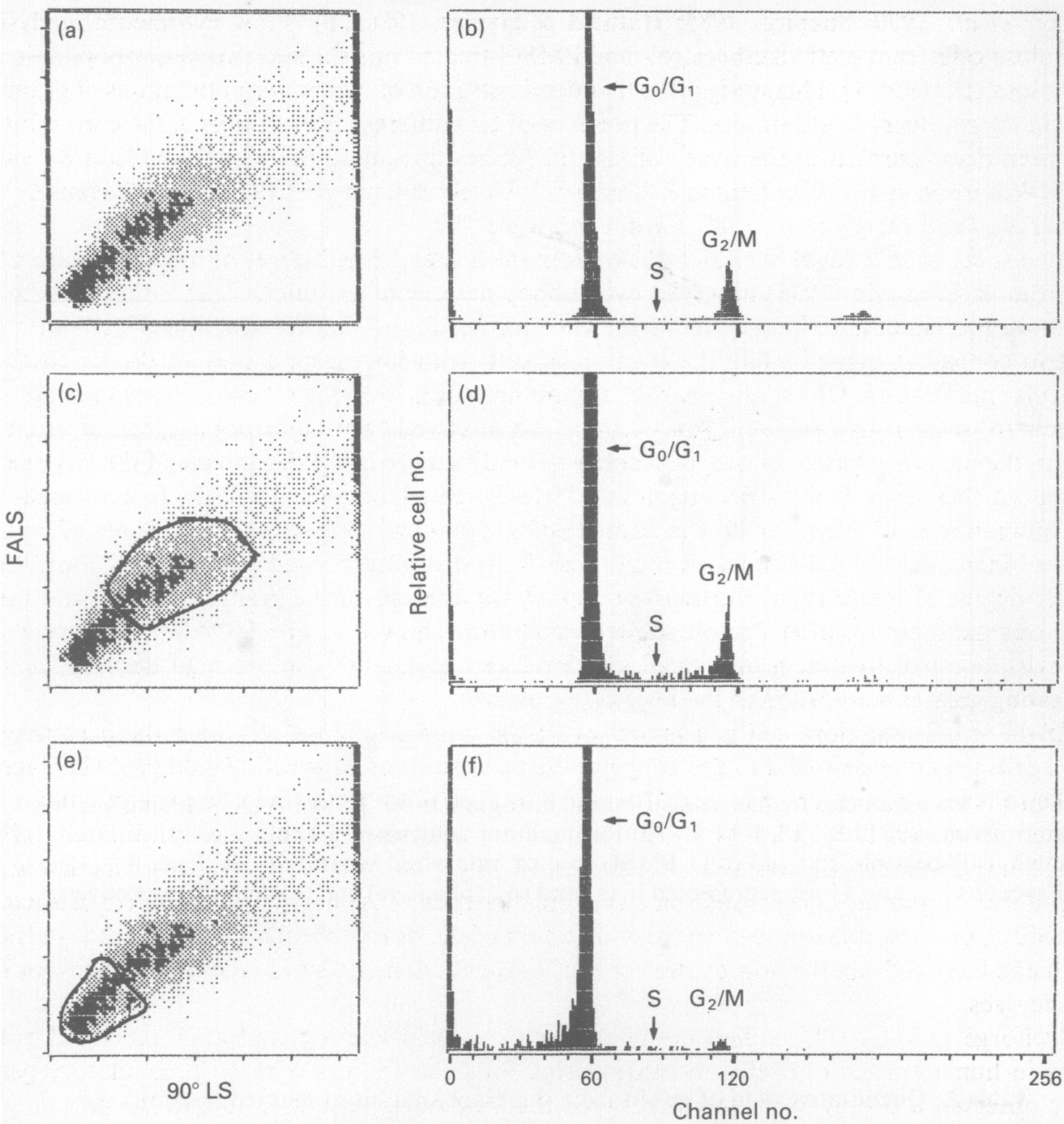

Fig. 4. Cell cycle analysis of granulosa cells from the large follicles of PMSG-treated rat ovaries. $(a, b)$ Total cells; (c, d) large cells; $(e, f)$ small cells.

represented cell clumps. Analysis of granulosa cells from other sizes of follicles of both treatment groups showed similar results.

\section{Discussion}

Granulosa cells obtained from rats treated with diethylstilboestrol or PMSG and separated into various fractions, using a Percoll gradient, showed differences in their ability to synthesize oestradiol and progesterone (Rao et al., 1991). Furthermore, light microscopic analysis demonstrated at least two major cell sizes, small cells ranging in diameter from 4.48 to $5.94 \mu \mathrm{m}$ and diameters of large cells ranging from 6.39 to $8.07 \mu \mathrm{m}$. In this study, flow cytometric analysis using the forward angle light scatter (FALS) and $90^{\circ}$ light scatter $\left(90^{\circ} \mathrm{LS}\right)$ was carried out to examine further the granulosa cell populations. FALS has been shown to reflect primarily cell size characteristics whereas factors such as cytoplasmic secretory granule content and distribution of cytoplasmic organelles influence the $90^{\circ}$ LS (Brunsting \& Mullaney, 1974; Meyer \& Brunsting, 1975; 
Kerker et al., 1979; Shapiro, 1985; Hatfield \& Hymer, 1986a, b). Flow cytometric analysis of granulosa cells from diethylstilboestrol- and PMSG-treated rats showed two major populations of granulosa cells (Fig. 1). This study is the first demonstration of two major populations of granulosa cells in the rat ovary based on size. The presence of two different sizes of cells in the corpus luteum has been demonstrated in the ovary of several species, including the rat (Donaldson \& Hansel, 1965; Wilkinson et al., 1976; Lemon \& Loir, 1977; Ursely \& Leymarie, 1979; Koos \& Hansel, 1981; Fitz et al., 1982; Ohara et al., 1987; Farin et al., 1988).

In a study of individual ovarian follicles from the hen at defined stages of follicular maturation, Marrone \& Crissman (1988) observed two subpopulations of granulosa cells within each follicle based on protein content rather than size. They further found that the fraction of cells with high protein content increased while the fraction of cells with low protein content decreased during follicular maturation. Our studies show that granulosa cells from the rat differ in several important aspects from the cells from hen. For example, we observed two major populations of granulosa cells in the rat ovary based on size, but there was no difference in the percentage of the large cells in granulosa cells from diethylstilboestrol- and PMSG-treated animals (Table 2). In agreement with the observations of Marrone \& Crissman (1988), granulosa cells from PMSG-treated animals showed increased $90^{\circ}$ LS compared with those from diethylstilboestrol-treated rats, indicating a higher degree of maturation. Furthermore, quadrant analysis of the granulosa cells from rats of both treatment groups after Percoll gradient separation showed greater $90^{\circ} \mathrm{LS}$ in small cells after diethylstilboestrol treatment and small and large cell populations in the high density fractions, indicating greater maturation in the PMSG population.

If the small granulosa cell is a precursor of the large granulosa cell, then the percentage of small cells would be expected to decrease and the percentage of large cells would probably increase as the follicles age and grow in size. This did not appear to be the case because granulosa cells isolated from small follicles $(<210 \mu \mathrm{m})$, medium follicles $(210-420 \mu \mathrm{m})$ and large follicles $(>420 \mu \mathrm{m})$ contained comparable percentages of large and small cells. In this experiment, the overall size of granulosa cells was somewhat smaller than those derived by chemical dissociation procedure, possibly due to use of enzymic digestion of the ovary to isolate follicles. The analysis of small and large cells on the flow cytometer was, however, done under identical conditions for the 3 follicle sizes.

Delforge et al. (1972) studied the relationship between nucleocytoplasmic ratio and mitotic index in human granulosa cells obtained during follicular maturation and preovulatory period. They observed a positive correlation between the nucleocytoplasmic ratio and the mitotic index during the follicular phase. However, before the LH surge, the mitotic index falls sharply before any change in the nucleocytoplasmic ratio, and so the correlation between these two parameters is lost. However, cellular volume increases. There was, therefore, evidence for the existence of mixed populations of granulosa cells at this time. Similarly, Westergaard et al. (1982) measured a low percentage $(<12 \%)$ of granulosa cells derived from preovulatory follicles in the ' $S$ ' phase of the cell cycle. These studies strongly suggest the existence of mixed populations, notwithstanding the mitotic activity of the granulosa cell pool.

The question raised in our studies was whether both the small and large cell populations undergo cell cycling. The results from flow cytometric cell cycle analysis showed that cycling occurred in both cell sizes. Thus they could represent two independent populations of cells. However, whether a small cell can lead to a large cell was not clearly answered by this study.

The results of this study show the presence of two cell populations of granulosa cells based on size. Preliminary results suggest that the small cell population persists in follicles with widely different states of growth and differentiation and also in follicles of different sizes. The individual role of small and large granulosa cells during follicle growth and steroidogenesis is therefore of considerable interest and is currently under further study in our laboratory.

This investigation is supported by a grant HD24488 from NICHD, NIH. 


\section{References}

Brunsting, A. \& Mullaney, P.F. (1974) Differential light scattering from spherical mammalian cells. Biophys. J. 14, 439-445.

Campbell, K.L. (1979) Ovarian granulosa cells isolated with EGTA and hypertonic sucrose: cellular integrity and function. Biol. Reprod. 21, 773-786.

Conway, B.A., Mahesh, V.B. \& Mills, V.B. (1990) Effect of dihydrotestosterone on the growth and function of ovarian follicles in intact immature female rats primed with PMSG. J. Reprod. Fert. 90, 267-277.

Delforge, J.P., Thomas, K., Roux, F., Carneiro De Siqueira, J. \& Ferin, J. (1972) Time relationships between granulosa cells growth and luteinization, and plasma luteinizing hormone discharge in human. A morphometric analysis. Fert. Steril. 23, 1-11.

Donaldson, L. \& Hansel, W. (1965) Histological study of bovine corpora lutea. J. Dairy Sci. 48, 905-909.

Farin, C.E., Moeller, C.L., Mayan, H., Gamboni, F., Sawyer, H.R. \& Niswender, G.D. (1988) Effect of luteinizing hormone and human chorionic gonadotropin on cell populations in the ovine corpus luteum. Biol. Reprod. 38, 413-421.

Fitz, T.A., Mayan, M.H., Sawyer, H.R. \& Niswender, G.D. (1982) Characterization of two steroidogenic cell types in the ovine corpus luteum. Biol. Reprod. 27, 703-711.

Hatfield, J.M. \& Hymer, W.C. (1986a) Flow cytometric analysis and sorting of live male rat anterior pituitary cell types by forward angle and perpendicular light scatter. Endocrinology 119, 2670-2682.

Hatfield, J.M. \& Hymer, W.C. (1986b) Flow cytometric analysis and sorting of live female rat anterior pituitary cell types by forward angle and perpendicular light scatter: effect of $17 \beta$-estradiol. Endocrinology 119, 2683-2694.

Kerker, M., Chew, H., McNulty, P.J., Kratohvil, J.P., Cooke, D.D., Schukey, M. \& Lee, M-P. (1979) Light scattering and fluorescence by small particles having internal structure. J. Histochem. Cytochem. 27, 250-263.
Koos, R.D. \& Hansel, W. (1981) The large and small cells of the bovine corpus luteum: Ultrastructural and functional differences. In Dynamics of Ovarian Function, pp. 197-203. Eds N. B. Schwartz \& M. Hunzicker-Dunn. Raven Press, New York.

Lemon, M. \& Loir, M. (1977) Steroid release in vitro by two luteal cell types in the corpus luteum of the pregnant sow. J. Endocr. 72, 351-359.

Marrone, B.L. \& Crissman, H.A. (1988) Characterization of granulosa cell subpopulations from ovarian preovulatory follicles by multiparameter flow cytometry. Endocrinology 122, 651-658.

Meyer, R.A. \& Brunsting, A. (1975) Light scattering from nucleated biological cells. Biophys. J. 15, 191-203.

Ohara, A., Mori, T., Taii, S., Ban, C. \& Narimoto, K. (1987) Functional differentiation of two types of luteal cells isolated from mature human corpora lutea of menstrual cycle. J. clin. Endocr. Metab. 65, $1192-1200$.

Rao, I.M., Mills, T.M., Anderson, E. \& Mahesh, V.B. (1991) Heterogeneity in granulosa cells of developing rat follicles. Anat. Rec. 229, 177-185.

Roy, S.K. \& Greenwald, G.S. (1985) An enzymatic method for dissociation of intact follicles from the hamster ovary: Histological and quantitative aspects. Biol. Reprod. 32, 203-215.

Shapiro, H.M. (1985) Practical Flow Cytometry. Alan R. Liss, Inc., New York.

Ursely, J. \& Leymarie, P. (1979) Varying responses to luteinizing hormone of two luteal cell types isolated from bovine corpus luteum. J. Endocr. 83, 303-310.

Westergaard, L., McNatty, K.P., Christensen, I., Larsen, J.K. \& Byskov, A.G. (1982) Flow cytometric deoxyribonucleic acid analysis of granulosa cells aspirated from human ovarian follicles. A new method to distinguish healthy and atretic ovarian follicles. J. clin. Endocr. Metab. 55, 693-698.

Wilkinson, R.F., Anderson, E. \& Aalberg, J. (1976) Cytological observations of dissociated rat corpus luteum. J. Ultrastruct. Res. 57, 168-184.

Received 9 June 1990 